\title{
Microbial protein net synthesis in sheep fed hay- concentrate diets supplemented with different source and level of fat
}

\author{
Malgorzata Szumacher-Strabel \\ Department of Animal Nutrition and Feed Management, \\ Poznán Agriculture University \\ Wolyńska 33, 60-637 Poznań, Poland
}

(Received 29 June 1998; accepted 22 September 1998)

\begin{abstract}
Three experiments in a $4 \times 4$ Latin square design were carried out on four rams fitted with rumen cannulas to investigate the effect of varying sources and levels of fat addition on microbial protein net synthesis (MN) in sheep fed a concentrate-based diet $(60 \%$ of concentrate and $40 \%$ of meadow hay). In the $1^{\text {st }}$ experiment addition of rape seed oil (RSO) was tested, linseed oil (LSO) was added in the $2^{\text {nd }}$, and tallow (TAL) in the in $3^{\text {rd }}$ experiment. Treatments in all experiments were similar: a control group without fat addition and experimental groups with 4,8 and $10 \%$ of fat in DM of the diet. Microbial production in the rumen, purine derivatives in urine, ruminal ammonia, $\mathrm{pH}$, fatty acids in the rumen were measured. In all cases fat addition resulted in decreased $\mathrm{MN}$, however, $8 \%$ fat suppiementation had the least deleterious effect on MN production. Fat addition significantly affected purine derivatives excretion. LSO as the supplemental fat led to a decrease in $\mathrm{N}$ ammonia concentration from $7.8 \mathrm{mmol} / \mathrm{L}$ in the control group to $6.39 \mathrm{mmol} / \mathrm{L}$ in the group that received $8 \%$ LSO, whereas a significant increase to $9.00 \mathrm{mmol} / \mathrm{L}$ was observed when $10 \% \mathrm{LSO}$ in DM was fed. Ruminal fluid $\mathrm{pH}$ was not altered by treatments. In all of the experiments, the increased fat content in the diets decreased the molar percentage of acetic acid. Supplementation of the diet with LSO and TAL resulted in an increase of the propionic acid level $(\mathrm{P}<0.05)$.
\end{abstract}

KEY WORDS: fat, concentrate, purine derivatives, microbial protein net synthesis, sheep

\section{INTRODUCTION}

High producing animals usually have a negative energy balance. Dietary energy density in the diet can be increased by incorporation of additional concentrate, 
supplemental fat or both (Grum et al., 1996). Supplementation with fat helps meet the energy requirement of ruminants without causing the metabolic disorders often observed when large amounts of grain are fed (Wu and Huber, 1994). Diets for ruminants are also supplemented with high-starch grains to increase energy density, however, the amount of grain that can be fed is limited because ruminants require fibre in the ration for adequate chewing activity and rumen function (Hoffman et al., 1991). Another discouragement to the use of high-starch concentrate diets in ruminant rations is their rapid fermentation, which causes a decrease in the $\mathrm{pH}$ in the rumen (Cone, 1991). The most efficient way to increase the energy concentration of a diet is to include fat. However, fat has an adverse effect on digestion of fibre in the rumen, often resulting in reduced feed intake (Houtert and Leng, 1993). Various effects of added fat depend on the level, source and type of fat, dietary carbohydrate source and feed intake (Garnsworthy, 1997).

The objective of this study was to investigate the effects of a high concentrate diet supplemented with different levels of fat on microbial net synthesis and other rumen parameters.

\section{MATERIAL AND METHODS}

\section{Animals and diets}

Four rams (average $\mathrm{BW}=60 \pm 3 \mathrm{~kg}$ ) with ruminal cannulas were assigned to three experiments. In all of the experiments the experimental design was a $4 \times 4$ Latin square with 16-d periods. The first $14 \mathrm{~d}$ were used for adaptation to the diet and the last 2 for sample collection. Sheep received diets consisting of $40 \%$ meadow hay, chopped into $5 \mathrm{~cm}$ and $60 \%$ concentrate, supplemented with 4,8 and $10 \%$ of fat on dry matter basis. The current study is a continuation of previous research based on hay diets (Szumacher-Strabel, 1998). Three experiments were carried out: the $1^{\text {st }}$ experiment with added rape seed oil (RSO), the $2^{\text {nd }}$ with linseed oil (LSO), and the $3^{\text {rd }}$ with tallow (TAL). Water was available ad libitum. The daily experimental ration, $1500 \mathrm{~g}$, was divided into two equal portions and fed at 08.00 and $15.00 \mathrm{~h}$. The energy value of the experimental rations was $5.31 \mathrm{MJ} \mathrm{NE} / \mathrm{kg}$, whereas the crude protein content was $144 \mathrm{~g}$ per $\mathrm{kg}$. Sheep were fed at the maintenance level plus $15 \%$.

\section{Sample collection and analysis}

Samples of rumen fluid and urine were collected and analyzed as described in a previous paper (Szumacher-Strabel, 1998). 


\section{Statistical analysis}

Data were analysed using SAS procedures (User's Guide, 1990).

\section{RESULTS AND DISCUSSION}

Feed costs account for some $70-75 \%$ of the total cost of ruminant livestock production and therefore it is imperative that the adopted principles of feeding practice are those which ensure the most efficient production of livestock products compatible with maximum economic return (Armstrong, 1980). In the case of high producing ruminants the first factor that has played a part in this strategy is covering energy and protein requirements. Starch is commonly added mainly to increase the energy density of feeds for ruminants, although, as mentioned in the introduction, high amounts of starch lead to rumen fermentation disturbances. In this case, the best way to decrease starch feeding is introducing fat into the rations. Increasing use of fat in feeding programmes has provided documented, consistent production responses when dietary fats were included at up to 5 to $6 \%$ of dietary DM (Pantoja et al., 1996). Fat supplementation (about 3\% of dietary DM) has often positively influenced the reproductive status of ruminants (Staples et al., 1998). Lipids added to ruminant diets can greatly disrupt fermentation in the rumen, causing reduced digestibility of nonlipid energy sources. Compared with fibre, dietary fat is less detrimental to digestibility of nonstructural carbohydrates (NSC) (Jenkins, 1993). Also Tackett et al. (1996) suggested that the type of fibre influenced the degree of negative effects caused by ruminally active fats. Elmeddah et al. (1991) did not demonstrate a significant interaction between the nature of the diet and fat. According to Elliot et al. (1995) replacement of NSC with supplemental fat decreases the amount of energy that is available for growth of ruminal microorganisms and may decrease microbial protein synthesis.

In the present experiment, in which diets containing $60 \%$ of concentrate were tested, in all cases fat addition resulted in decreased MN (Figure 1). Compared with previous experiments (Szumacher-Strabel, 1998), where sheep were fed hay diets, NM production in sheep fed concentrate-based diets tended to be slightly higher, but the results of the previous study, when hay diets were fed, were more

uniform. Similarly, in the experiment of Perez et al. (1997) when sheep were fed diets consisting of rations with two forage:concentrate ratios (low concentrate-LC and high concentrate-HC) urinary excretion of purine derivatives and microbial yield were higher in animals offered $\mathrm{HC}$ than in those that were offered LC. In our studies the results were similar for all kinds of fat and statistically significant differences were not observed $(\mathrm{P}>0.05)$. Neither source and type of fat nor dietary carbohydrate source had an effect on net MN level when $8 \%$ of fat was added. 
However, when the level of added fat was below or above this level, a high variability in MN production was observed, particularly with tallow, which is difficult to explain.

Inclusion of linseed oil increased efficiencies of ruminal microbial protein synthesis, but this was accompanied by decreased ammonia concentration and increased N flow into the duodenum. According to Jenkins (1993) these increased efficiencies have been attributed to an increased dilution rate of solids in the rumen because of the added fat. Similarly, the efficiency of bacterial protein synthesis was increased when whole canola seeds were supplemented to diets with two forage levels ( 70 vs. $30 \%$ in DM) in the experiment of Hussein et al. (1996).

The level of total purine derivatives (PD) in urine was estimated and microbial protein net synthesis was calculated, similarly as in previous studies, using allantoin as the indicator. There were no statistically significant differences between the groups and experiments (Figures 2 to 5). Surra et al. (1997) conclude that urinary excretion of PD may be affected by variations in the flow of undigested fibre along the small intestine. Figure 6 presents the changes in the amount of total purine derivatives for all of the added fats. Addition of fat to concentrate-based diets, in contrast with hay-based diets, caused a larger variation in the level of purine derivatives excreted. In the experiment of Vagnoni and Broderic (1997), protein synthesis was poorer in cows that consumed lucerne conserved as hay than as lucerne silage. Source, amount, and physical characteristics of dietary forage can interact with nonforage fibre sources and influence ruminal fibre digestion, passage, and performance of dairy cows fed diets containing substantial amounts of nonforage fibre in place of forage (Grant, 1997). According to Allen (1997) ruminal fermentation of both nonfibre carbohydrate and fibre is extremely variable, and this variability is not related to the nonfibre carbohydrate content of the diet. In spite of such large variability, neither carbohydrate source nor fat addition affected $\mathrm{PD}$ excretion in sheep fed concentrate-based diets in a statistically significant $(\mathrm{P}>0.05)$ manner.

Supplementary tallow had no effect on the ruminal ammonia $\mathrm{N}$ level. When LSO was the supplementary fat, a decrease in $\mathrm{N}$ ammonia concentration was observed in the group receiving $8 \% \mathrm{LSO}$ (from $7.8 \mathrm{mmol} / \mathrm{L}$ in the control group to $6.39 \mathrm{mmol} / \mathrm{L}$ ), whereas a statistically significant increase was observed when $10 \%$ LSO in DM was fed (Figure 7). The concentration of $\mathrm{NH}_{3}-\mathrm{N}$ in ruminal fluid increased slightly $(\mathrm{P}<0.07)$ when supplemental fat as tallow was fed (Weigel et al., 1997). Satter and Slyter (Ivan et al., 1996) suggested that concentrations of 5 to 8 $\mathrm{mg}$ of ammonia $\mathrm{N} / 100 \mathrm{~mL}$ of ruminal fluid were optimal for maximizing microbial mass yield and that concentrations $<2 \mathrm{mg} / 100 \mathrm{~mL}$ were potentially limiting for microbial growth. However, other studies have indicated that chemical or structural characteristics of the degradable substrate might influence estimates of optimal ruminal ammonia $\mathrm{N}$ for microbial growth. Diets in the present experiments were 


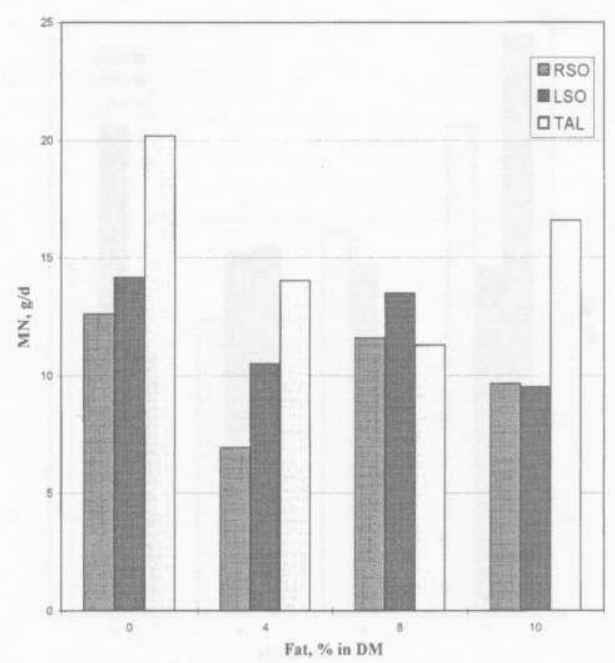

Figure 1. Effect of RSO, LSO and TAL on microbial protein $(\mathrm{MN})$ production

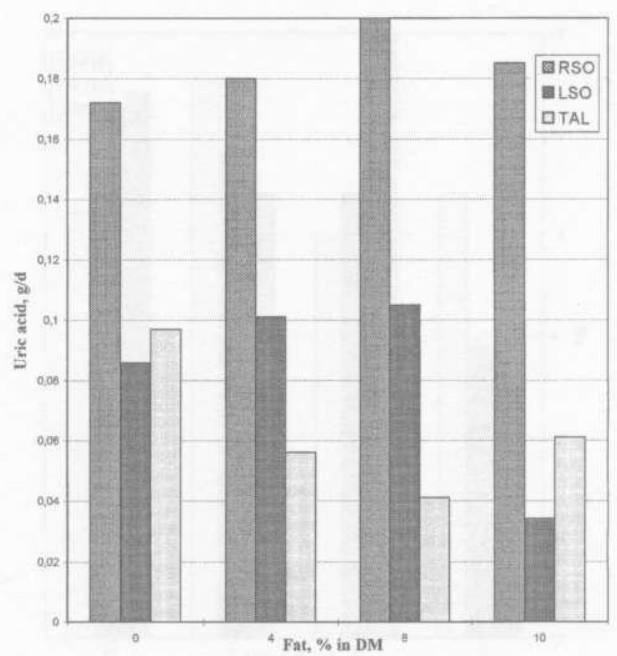

Figure 3. Effect of RSO, LSO and TAL on uric acid in urine of sheep

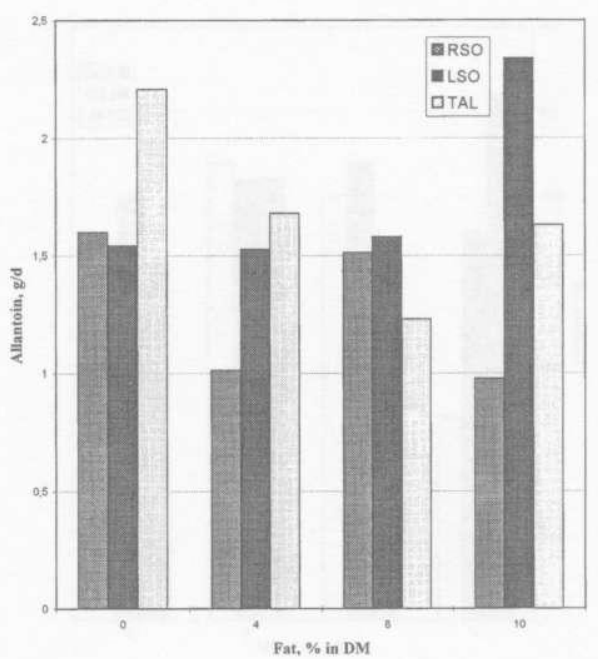

Figure 2. Effect of RSO, LSO and TAL on allantoin in urine of sheep

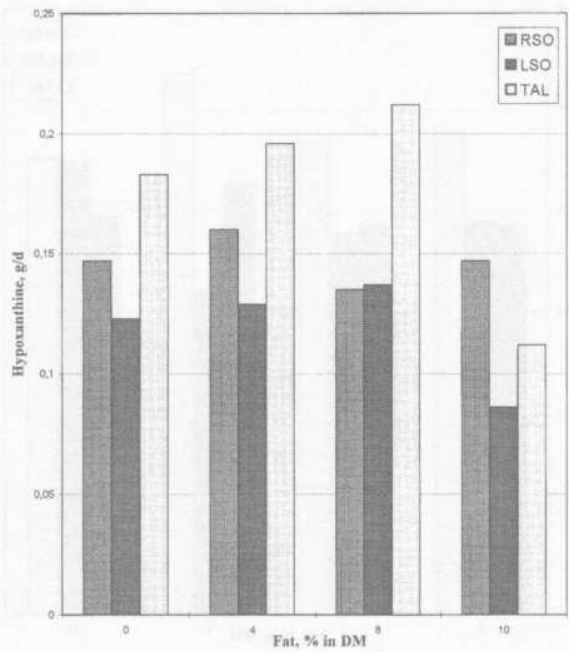

Figure 4. Effect of RSO, LSO and TAL on hypoxanthine in urine of sheep

sufficient for maximal microbial growth yield and also to meet the energy requirements of animals.

Ruminal fluid $\mathrm{pH}$ was not altered by treatments $(\mathrm{P}>0.05)$ (Figure 8$)$ although it seems that concentrate-based diets tended to decrease the $\mathrm{pH}$ in comparison with hay-based diets. Madison-Anderson et al. (1997) reported that $\mathrm{pH}$ and ammonia 


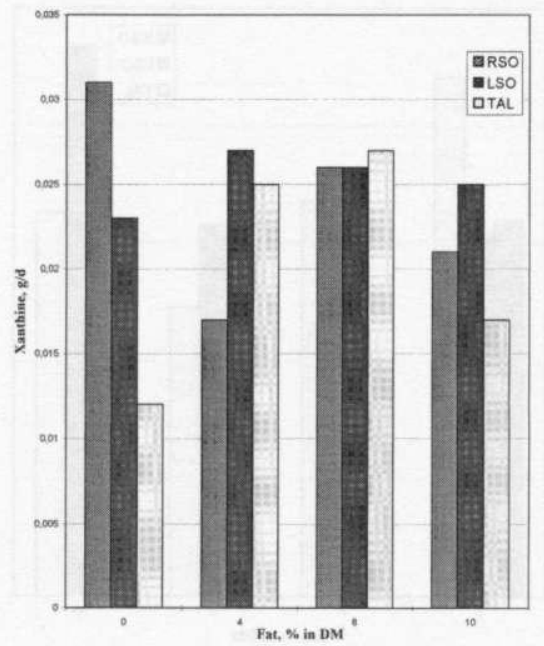

Figure 5. Effect of RSO, LSO and TAL on xanthine in urine of sheep

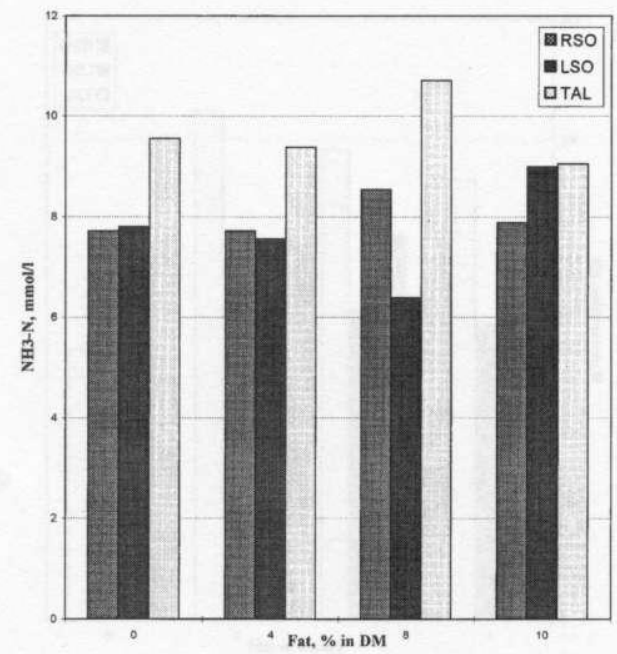

Figure 7. Effect of RSO, LSO and TAL on $\mathrm{NH}_{3}-\mathrm{N}$ concentration in rumen fluid

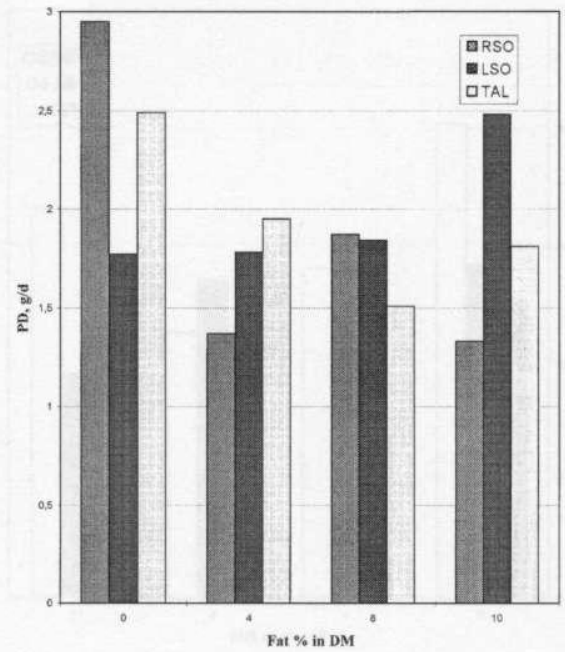

Figure 6. Effect of RSO, LSO and TAL on total purine derivatives (PD) content in urine

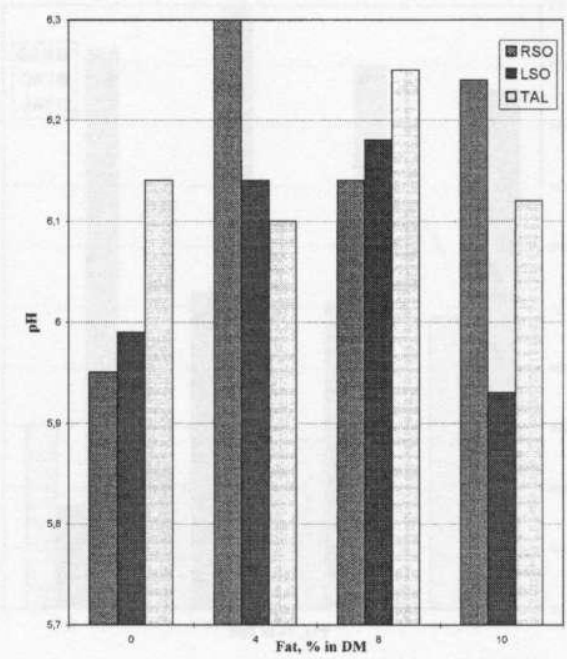

Figure 8. Effect of RSO, LSO and TAL on rumen fluid $\mathrm{pH}$

were unaffected by supplemental fat ( $3 \%$ of DM extruded soyabeans). Low ruminal $\mathrm{pH}$ may decrease DMI, fibre digestibility, and microbial yield and increase feed costs (Allen, 1997).

Acid production in the rumen is due primarily to fermentation of carbohydrates, which represent over $65 \%$ of the DM in diets of ruminants (Allen, 1997). In all of 
TABLE 1

Effect of rapeseed oil on concentration of total and individual VFA

\begin{tabular}{lcccccccc}
\hline & \multicolumn{7}{c}{ Group } \\
\cline { 2 - 8 } Acids & I & \multicolumn{1}{c}{ II } & III & IV & \\
mmol/L & control & SD & $4 \%$ fat & SD & $8 \%$ fat & SD & $10 \%$ fat & SD \\
\hline Acetic & $35.03^{\mathrm{b}}$ & 6.55 & $42.30^{\mathrm{a}}$ & 9.05 & $31.30^{\mathrm{b}}$ & 7.23 & $25.37^{\mathrm{c}}$ & 6.21 \\
Propionic & 29.90 & 4.83 & 32.09 & 5.56 & 31.18 & 6.82 & 34.36 & 7.37 \\
Butyric & 10.30 & 3.44 & 10.29 & 2.00 & 10.60 & 2.68 & 12.48 & 2.47 \\
Isobutyric & 3.33 & 0.91 & 3.47 & 0.71 & 2.76 & 1.07 & 3.02 & 1.22 \\
Valeric & $3.59^{\mathrm{a}}$ & 0.93 & $3.00^{\mathrm{ab}}$ & 1.12 & $2.27^{\mathrm{b}}$ & 0.81 & $3.63^{\mathrm{a}}$ & 0.84 \\
Isovaleric & $3.05^{\mathrm{a}}$ & 0.84 & $3.58^{\mathrm{a}}$ & 0.90 & $1.55^{\mathrm{b}}$ & 0.76 & $1.67^{\mathrm{b}}$ & 0.80 \\
Total VFA & $85.22^{\mathrm{AB}}$ & 12.78 & $94.75^{\mathrm{A}}$ & 15.32 & $79.66^{\mathrm{B}}$ & 13.96 & $80.56^{\mathrm{B}}$ & 13.12 \\
\hline
\end{tabular}

$\mathrm{a}, \mathrm{b}, \mathrm{c}-\mathrm{P}<0.05$

TABLE 2

Effect of linsecd oil on concentration of total and individual VFA

\begin{tabular}{|c|c|c|c|c|c|c|c|c|}
\hline \multirow[b]{2}{*}{$\begin{array}{l}\text { Acids } \\
\mathrm{mmol} / \mathrm{L}\end{array}$} & \multicolumn{8}{|c|}{ Group } \\
\hline & $\begin{array}{c}\text { I } \\
\text { control }\end{array}$ & $\mathrm{SD}$ & $\begin{array}{c}\text { IJ } \\
4 \% \text { fat }\end{array}$ & $\mathrm{SD}$ & $\begin{array}{c}\text { III } \\
8 \% \text { fat }\end{array}$ & SD & $\begin{array}{c}\text { IV } \\
10 \% \text { fat }\end{array}$ & SD \\
\hline Acetic & $36.95^{\mathrm{a}}$ & 7.23 & $33.54^{\mathrm{ab}}$ & 5.48 & $33.03^{\mathrm{ab}}$ & 4.11 & $30.64^{b}$ & 3.09 \\
\hline Propionic & $24.30^{\circ}$ & 4.27 & $26.54^{\mathrm{bc}}$ & 3.67 & $30.20^{\mathrm{h}}$ & 4.19 & $37.59^{\mathrm{a}}$ & 4.43 \\
\hline Butyric & 8.54 & 3.46 & 8.66 & 2.90 & 8.55 & 2.59 & 9.50 & 3.14 \\
\hline Isobutyric & 2.58 & 0.90 & 2.83 & 0.91 & 3.37 & 1.13 & 2.80 & 0.54 \\
\hline Valeric & 2.54 & 0.90 & 2.41 & 0.59 & 2.57 & 0.52 & 2.42 & 0.55 \\
\hline Isovaleric & 2.21 & 0.64 & 2.18 & 0.70 & 2.63 & 0.65 & 2.41 & 0.58 \\
\hline Total VFA & 77.15 & 13.30 & 76.18 & 10.05 & 80.37 & 10.66 & 85.36 & 7.25 \\
\hline
\end{tabular}

a, b, c $-\mathrm{P}<0.05$

the described experiments the increased fat content in the diets decreased the molar percentage of acetic acid. In experiments with LSO and TAL elevated levels of propionic acid were observed $(\mathrm{P}<0.05)$ (Tables 1 to 3$)$. Increasing the LSO and TAL levels also caused a rise in propionic acid levels. Similarly, the molar proportions of acetate tended to decrease and molar proportions of propionate tended to increase in the ruminal fluid when fat was fed in Schauff's ct al. (1992) experiment.

The theory that the ratio of acetate to propionate produced in the rumen determines the energetic efficiency of growth has been tested extensively (Houtert and Leng, 1993). According to Schauff et al. (1992) ruminal fermentation is not altered greatly when ruminants ingest large amounts of feed and animal fats do not exceed $4 \%$ of dietary DM. 
Effect of tallow on concentration of total and individual VFA

\begin{tabular}{|c|c|c|c|c|c|c|c|c|}
\hline \multirow[b]{2}{*}{$\begin{array}{l}\text { Acids } \\
\mathrm{mmol} / \mathrm{L}\end{array}$} & \multicolumn{8}{|c|}{ Group } \\
\hline & $\begin{array}{c}\text { I } \\
\text { control }\end{array}$ & SD & $\begin{array}{c}\text { II } \\
4 \% \text { fat }\end{array}$ & SD & $\begin{array}{c}\text { III } \\
8 \% \text { fat }\end{array}$ & SD & $\begin{array}{c}\text { IV } \\
10 \% \text { tat }\end{array}$ & SD \\
\hline Acetic & $36.28^{4}$ & 4.64 & $34.39^{\prime \prime}$ & 4.02 & $32.58^{\mathrm{a}}$ & 5.43 & $26.65^{\mathrm{h}}$ & 4.07 \\
\hline Propionic & $26.29^{\mathrm{h}}$ & 4.22 & $25.44 \mathrm{~b}$ & 4.91 & $28.34^{b}$ & 4.49 & $36.12^{\mathrm{a}}$ & 5.24 \\
\hline Butyric & 10.42 & 2.74 & 8.42 & 2.83 & 8.57 & 2.74 & 10.84 & 1.76 \\
\hline Isobutyric & 2.91 & 0.84 & 3.32 & 2.28 & 2.36 & 0.69 & 2.90 & 1.20 \\
\hline Valeric & $3.19^{\mathrm{ab}}$ & 0.94 & $3.14^{\mathrm{ab}}$ & 0.88 & $2.91^{\mathrm{b}}$ & 0.91 & $3.88^{\mathrm{n}}$ & 0.50 \\
\hline Isovaleric & $2.63^{i}$ & 0.61 & $2.60^{\mathrm{a}}$ & 0.50 & $2.61^{a}$ & 0.46 & $2.02^{\mathrm{b}}$ & 0.51 \\
\hline Total VFA & 81.74 & 10.25 & 77.33 & 10.48 & 77.40 & 10.83 & 82.44 & 9.83 \\
\hline
\end{tabular}

$a, b, c-P<0.05$

Garnsworthy (1997) suggested that if added dietary fats interfere with normal fibre digestion in the rumen, acetate and butyrate production will be reduced. In the present experiment, the molar percentage of butyrate was not altered by fat addition, whereas supplementing fat in Weigel's et al. (1997) experiment slightly decreased $(\mathrm{P}<0.08)$ the butyrate level. In the experiment of Grummer et al. (1993), butyrate responded quadratically as tallow supplementation was increased. In the present experiment, an increased RSO and TAL ratio generally decreased $(\mathrm{P}<0.05)$ the molar percentage of isovalerate and valerate.

A less deleterious effect of fat on the molar proportion of fatty acids and moderate changes in other VFA patterns were observed when linseed oil was fed. Ruminal VFA patterns of sheep were not altered when $10 \%$ canola fatty acids were added to a diet containing ground lucerne hay (Tackett et al., 1996). Volatile fatty acid concentrations in the rumen were similar for diets consisting of $60 \%$ meadow hay as for diets composed of $65 \%$ maize silage supplemented with $7 \%$ RSO on a DM basis (Ben Salem, 1993).

As expressed in the previous study, the composition of the basal diet also may influence how a fat source affects ruminal fermentation (Szumacher-Strabel, 1998). According to Jenkins (1993) fats that normally inhibit fermentation and digestion often cause less inhibition when the hay content of the basal diet is high.

The obtained results are similar when compared with previous paper (Szumacher-Strabel, 1998). The results of these two studies indicate that addition of fat to sheep rations does not influence $\mathrm{MN}$ production to a significant degree. Additional research is needed to investigate the proper forage:concentrate level when fat is added to sheep rations so as not to greatly alter ruminal fermentation. 


\section{REFERENCES}

Allen M.S., 1997. Relationship between fermentation acid production in the rumen and the requirement for physically effective fiber. J. Dairy Sci. 80, 1447-1462

Armstrong D.G., 1980. Some aspects of nitrogen digestion in the ruminant and their practical significance. The $2^{\text {nd }}$ Tom Miller Memorial Lecturc. pp. 1-16

Ben Salem H., Krzeminski R., Ferlay A., Doreau M.. 1993. Effect of lipid supply on in vivo digestion in cows: Comparison of hay and corn silage. Can. J. Anim. Sci. 73, 547-557

Cone J.W., 1991. Degradation of starch in feed concentrates by enzymes, rumen fluid and rumen enzymes. J. Sci. Food Agric. 54, 23-34

Elliott J.P., Drackley J.K., Fahey G.C., Shanks R.D., 1995. Utilization of supplemental fat by dairy cows fed diets varying in content of nonstructural carbohydrates. J.Dairy Sci. 78, 1512-1525

Elmeddah Y., Doreau M., Michalet-Doreau B., 1991. Interaction of lipid supply and carbohydrates in the diet of sheep with digestibility and ruminal digestion. J. Agric. Sci., Camb. 116, 437-445

Garnsworthy P.C., 1997. Recent Advances in Animal Nutrition. Nottingham University Press, pp. $87-104$

Grant R.J., 1997. Interactions among forages and nonforage fiber sources. J. Dairy Sci. 80, $1438-1446$

Grum D.E., Drackley J.K., Hansen L.R., Cremin J.D., Jr., 1996. Production, digestion, and hepatic lipid metabolism of dairy cows fed increased energy from fat or concentrate. J. Dairy Sci. 79 , $1836-1849$

Grummer R.R., Luck M.M., Barmore J.A., 1993. Rumen fermentation and lactation performance of cows fed roasted soybeans and tallow. J.Dairy Sci. 76, 2674-2681

Hoffman P.C., Grummer R.R., Shaver R.D., Broderick G.A., Drendel T.R., 1991. Feeding supplemental fat and undegraded intake protein to early lactation dairy cows. J. Dairy Sci. 74, 3468-3474

Houtert M.F.J., Leng R.A., 1993. The effect of supplementation with protein, lipid and propionate on nutrient partitioning in roughage-fed lambs. Anim. Prod. 56, 341-349

Hussein H.S., Merchen N.R., Fahey G.C., 1996. Effects of forage percentage and canola seed on ruminal protein metabolism and duodenal flows of amino acids in steers. J. Dairy Sci. 79 , 98-104

Ivan M., Mahadevan S., Dayrell M. de S., 1996. Duodenal flow of microbial and feed nitrogen in sheep fed normal soybean meal or soybean meal treated with modified zein. J. Dairy Sci, 79, $121-126$

Jenkins T.C., 1993. Symposium: Advances in ruminant lipid metabolism. Lipid metabolism in the rumen. J. Dairy Sci. 76, 3851-3863

Madison-Anderson R.J., Schingoethe D.J., Brouk M.J., Baer R.J., Lentsch M.R., 1997. Response of lactating cows to supplemental unsaturated fat and niacin. J. Dairy Sci. 80, 1329-1338

Pantoja J., Firkins J.L., Eastridgc M.L., Hull B.L., 1996. Fatly acid digestion in lactating dairy cows fed fats varying in degree of saturation and different fiber sources. J. Dairy Sci.79, 575-585

Perez. J.F., Balcells J., Guada J.A., Castrillo C., 1997. Rumen microbial production estimated either from urinary purine derivative excretion or from direct measurements of ${ }^{15} \mathrm{~N}$ and purine bases as microbial markers; effect of protein source and rumen bacteria isolates. Anim. Sci. 65, 225-236

SAS, 1990. SAS/STAT Users guide (Release 6.03). SAS Institute INC., Cary, NC, USA

Schauff D.J., Elliott J.P., Clark J.H., Drackley J.K., 1992. Effects of feeding lactating dairy cows diets containing whole soybeans and tallow. J. Dairy Sci. 75, 1923-1935 
Staples C.R., Burke J.M., Thatcher W.W., 1998. Influence of supplemental fats on reproductive tissues and performance of lactating cows. J. Dairy Sci. 81, 856-871

Surra J.C., Guada J.A., Balcells J., Castrillo C., 1997. Effects of post-ruminal fermentation on the faecal and urinary excretion of purines. Anim. Sci. 65, 383-390

Szumacher-Strabel M., 1998. Microbial protein net synthesis in sheep fed meadow hay supplemented with different sources and level of fat. J. Anim. Feed Sci., 7, 385-394

Tackett V.L., Bertrand J.A., Jenkins T.C., Pardue F.E., Grimes L.W., 1996. Interaction of dietary fat and acid detergent fiber diets of lactating dairy cows. J. Dairy Sci. 79, 270-275

Vagnoni D.B., Broderick G.A., 1997. Effects of supplementation of energy or ruminally undegraded protein to lactating cows fed alfalfa hay or silage. J. Dairy Sci. 80, 1703-1712

Weigel D.J., Elliott J.P., Clark J.H., 1997. Effects of amount and ruminal degradability of protein on nutrient digestibility and production by cows fed tallow. J. Dairy Sci. 80, 1150-1159

Wu Z., Huber J.T., 1994. Relationship between dietary fat supplementation and milk protein concentration in lactating cows: A review. Livest. Prod. Sci. 39, 141-155

\section{STRESZCZENIE}

Synteza bialka mikroorganizmów u owiec żywionych dawkami zlożonymi siana i paszy treściwej $\mathrm{z}$ dodatkiem różnego rodzaju i ilości thuszczu

Przeprowadzono trzy doświadczenia na czterech trykach z trwałymi kaniulami żwaczowymi, w których badano wpływ diety składającej się z paszy treściwej i objętościowej (60:40\%) z dodatkiem thuszczu w postaci oleju rzepakowego (RSO) - doświadczenie 1, oleju Inianego (LSO) - doświadczenie 2 oraz łoju (TAL) - doświadczenie 3, na syntezę białka mikroorganizmów w żwaczu, poziom pochodnych purynowych w moczu, poziom azotu amonowego i lotnych kwasów thuszczowych w żwaczu oraz pH płynu żwaczowego. Dawkę pokarmową skarmiano w dwóch odpasach. Doświadczenia przeprowadzano w układzie kwadratu łacińskiego 4 × 4 testując w czterech grupach różne poziomy dodanego tłuszczu: 1 - grupa kontrolna bez dodatku tłuszczu, 2 - dodatek $4 \%$ tłuszczu (RSO, LSO lub TAL) w sm, 3 - dodatek $8 \%$ tłuszczu (RSO, LSO lub TAL) w sm, 4 - dodatek $10 \%$ thuszczu (RSO, LSO lub TAL) w sm. Dodatek tłuszczu zmniejszał produkcję białka mikroorganizmów, lecz różnice te nie były statystycznie istotne. Źródło tłuszczu oraz jego poziom w dawce nie miały wpływu na poziom pochodnych purynowych w moczu owiec oraz na pH płynu żwaczowego. Dodatek $8 \%$ oleju lnianego do diety istotnie $(\mathrm{P}<0,05)$ obniżył, natomiast $10 \%$ dodatek istotnie $(\mathrm{P}<0,05)$ zwiększył poziom azotu amonowego. We wszystkich doświadczeniach dodatek thuszczu obniżył $(\mathrm{P}<0,05)$ poziom kwasu octowego w płynie żwacza, natomiast olej Iniany i łój zwiększyły $(\mathrm{P}<0,05)$ produkcje kwasu propionowego we wszystkich grupach. 